\title{
Prednisone in MOPP chemotherapy for Hodgkin's disease
}

\author{
CHARLOTTE JACOBS, CAROL S PORTLOCK, SAUL A ROSENBERG
}

\begin{abstract}
Summary
High remission rates have been produced by MOPP (mustine, vincristine, procarbazine, and prednisone) chemotherapy in patients with advanced Hodgkin's disease, but the prednisone component has caused adverse effects in patients who have undergone radiotherapy. The remission rates and length of remission were reviewed in 211 patients with Hodgkin's disease who received chemotherapy either with or without prednisone. In contrast to the findings of a British study, there were no significant differences in remission rates or length of remission between patients who had received prednisone and patients who had not. There were differences between the British prospective study and this retrospective one, but it is difficult to know what accounted for the substantial differences in the findings.
\end{abstract}

\section{Introduction}

When combination chemotherapy with mustine, vincristine (Oncovin), procarbazine, and prednisone (MOPP) was first used to treat Hodgkin's disease, prednisone was included because it was thought to be an effective agent without bone marrow toxicity. ${ }^{1}$ High complete remission rates $(81 \%)$ have been reported after treatment with MOPP in which prednisone 40 $\mathrm{mg} / \mathrm{m}^{2}$ was given for 14 days in cycles 1 and 4. ${ }^{2}$ But Castellino et $\mathrm{al}^{3}$ described seven patients who had had mantle irradiation and who developed pneumonitis or pericarditis shortly after completing either cycle 1 or cycle 4 . It was thought that subclinical radiation injury to the lungs or heart might be activated by rapid withdrawal of high-dose steroids. Consequently, at Stanford, we eliminated prednisone from the regimen in those

\footnotetext{
Division of Oncology, Department of Medicine, Stanford University School of Medicine, Stanford, California 94305

CHARLOTTE JACOBS, MD, fellow in oncology

CAROL S PORTLOCK, $M D$, acting assistant professor

SAUL A ROSENBERG, MD, professor of medicine and radiology
}

patients who had received mediastinal irradiation. A recent prospective study by the British National Lymphoma Investigation group compared MOPP (with prednisone at $25 \mathrm{mg} / \mathrm{m}^{2}$ on days 1 to 14 in every cycle) with the same combination without prednisone (MOP) in patients with stage IV Hodgkin's disease; a highly significant difference in complete remission rates was found. ${ }^{4}$

We report here a retrospective analysis of 211 patients with Hodgkin's disease who received $M O P(P)$, comparing the complete remission rate and disease-free survival in those patients who did and did not receive prednisone.

\section{Patients and methods}

From June 1968 and December 1975257 patients with advanced Hodgkin's disease were treated at Stanford Medical Centre with MOPP as initial treatment for stage IV disease or for relapse after initial radiation therapy. Fourteen patients were excluded from the study because they were still being treated. Thirty-two patients were eliminated because we had insufficient data on their use of prednisone or insufficient follow-up data.

All biopsy specimens were reviewed at Stanford and classified according to the histopathological criteria of the Rye conference. ${ }^{5}$ Before starting chemotherapy patients were evaluated to assess the extent of disease with physical examination, chest $x$-ray examination, bone marrow biopsy, lymphography, and biopsy of appropriate extranodal tissue or staging laparotomy.

The chemotherapy administered was MOPP, as described by DeVita $e t a l^{2}$ : intravenous mustine $6 \mathrm{mg} / \mathrm{m}^{2}$ on days 1 and 8 , intravenous vincristine $1.4 \mathrm{mg} / \mathrm{m}^{2}$ on days 1 and 8 (not to exceed $2 \mathrm{mg}$ per injection), oral procarbazine $100 \mathrm{mg} / \mathrm{m}^{2}$ daily for 14 days, and oral prednisone $40 \mathrm{mg} / \mathrm{m}^{2}$ daily for 14 days on the first and fourth cycle. The MOPP cycle was repeated every 28 days, blood counts permitting. In a non-randomised fashion prednisone was either $(a)$ given in cycles 1 and 4 as described above; or $(b)$ omitted from all cycles because of previous mantle irradiation; or (c) given only in cycle 1 because of corticosteroid intolerance or because the patient received less than four cycles of drugs.

After six cycles the patients' remission status was assessed by repeat examination or biopsy, or both. No second-look laparotomies were performed. The length of complete response was calculated from the date of completing MOPP treatment to the first objective evidence of relapse. Curves for the probability of disease-free survival were calculated by the methods of Kaplan and Meier. ${ }^{6}$ Tests for significance between disease-free survival curves were performed with the method of Gehan.? 
Two comparisons were made. Patients who received prednisone in cycles 1 and 4 were compared with those who received no prednisone but completed at least four cycles of MOP. This comparison eliminated patients who received fewer than four cycles of therapy, thus making the complete remission rate seem higher. To include all patients we therefore compared two other groups. Patients who received some prednisone (including those who received the drug in cycles 1 and 4 or only in cycle 1) were compared with those who received no prednisone, regardless of the number of cycles of MOP. The complete response rate and length of remission were compared for the major groups as well as for all subgroups in which there was a significant difference in the numbers between the prednisone and no-prednisone groups.

Although the patients who received prednisone were comparable to those who received no prednisone in most respects, there was some patient selection. Significantly more patients in the prednisone groups had lung disease while more patients who did not take prednisone had lymph node involvement as the most advanced site of disease. The groups were otherwise comparable with respect to more advanced sites of disease. Significantly more of those who had no prednisone had received irradiation, usually because mantle irradiation was a reason for withholding prednisone. Finally, there were more patients in the four-cycle prednisone group who were under 20 years of age, although other age groups were comparable. Tables I and II show the details of the patients.

TABLE I-Characteristics of patients who received prednisone in cycles 1 and 4 and patients who received no prednisone but completed 4 cycles of chemotherapy

\begin{tabular}{|c|c|c|c|c|}
\hline & \multicolumn{2}{|c|}{$\begin{array}{l}\text { Patients taking } \\
\text { prednisone }\end{array}$} & \multicolumn{2}{|c|}{$\begin{array}{l}\text { Patients taking } \\
\text { no prednisone }\end{array}$} \\
\hline & No & $\%$ & No & $\%$ \\
\hline $\begin{array}{l}\text { No of patients } \\
\text { Sex: }\end{array}$ & 113 & 100 & 45 & 100 \\
\hline $\begin{array}{l}\text { Female } \\
\text { Male }\end{array}$ & $\begin{array}{l}44 \\
69\end{array}$ & $\begin{array}{l}38 \cdot 9 \\
61 \cdot 1\end{array}$ & $\begin{array}{l}16 \\
29\end{array}$ & $\begin{array}{l}35 \cdot 6 \\
64 \cdot 4\end{array}$ \\
\hline $\begin{array}{l}\text { Age: } \\
<20 \\
20-40 \\
>40\end{array}$ & $\begin{array}{l}21 \\
65 \\
27\end{array}$ & $\begin{array}{l}18 \cdot 6 \\
57 \cdot 5 \\
24 \cdot 0\end{array}$ & $\begin{array}{r}3 \\
32 \\
10\end{array}$ & $\begin{array}{r}6 \cdot 7 \\
71 \cdot 1 \\
22 \cdot 2\end{array}$ \\
\hline $\begin{array}{l}\text { Histology: } \\
\text { Lymphocyte predominance }\end{array}$ & & & & \\
\hline Nodular sclerosis & 78 & $69 \cdot 0$ & 35 & $77 \cdot 8$ \\
\hline Mixed cellularity & 21 & $18 \cdot 6$ & 6 & $13 \cdot 3$ \\
\hline $\begin{array}{l}\text { Lymphocyte depletion } \\
\text { Unclassified }\end{array}$ & $\begin{array}{l}5 \\
9\end{array}$ & $\begin{array}{l}4 \cdot 4 \\
8 \cdot 0\end{array}$ & $\begin{array}{l}2 \\
2\end{array}$ & $\begin{array}{l}4 \cdot 4 \\
4 \cdot 4\end{array}$ \\
\hline Site*: & & & & \\
\hline Nodes & 29 & $25 \cdot 7 \dagger$ & 19 & $42 \cdot 2 \dagger$ \\
\hline Lung & 39 & 34.5 & 9 & $20 \cdot 0$ \\
\hline Liver & 9 & $8 \cdot 0$ & 3 & $6 \cdot 7$ \\
\hline Osseous & 5 & & 4 & 8.9 \\
\hline Bone marrow & 29 & $25 \cdot 7$ & 9 & $20 \cdot 0$ \\
\hline Other & 2 & $1 \cdot 8$ & 1 & $2 \cdot 2$ \\
\hline $\begin{array}{l}\text { Prior irradiation } \\
\text { No prior irradiation }\end{array}$ & $\begin{array}{l}69 \\
44\end{array}$ & $\begin{array}{l}61 \cdot 1 \dagger \\
38.9 \dagger\end{array}$ & $\begin{array}{r}44 \\
1\end{array}$ & $\begin{array}{r}97 \cdot 8+ \\
2 \cdot 2+\end{array}$ \\
\hline
\end{tabular}

*Most advanced site, in order listed.

$+\mathrm{P}<0.05$.

TABLE II-Characteristics of patients who received some prednisone and those who received no prednisone, regardless of number of cycles of chemotherapy

\begin{tabular}{|c|c|c|c|c|}
\hline & \multicolumn{2}{|c|}{$\begin{array}{l}\text { Patients taking } \\
\text { prednisone }\end{array}$} & \multicolumn{2}{|c|}{$\begin{array}{l}\text { Patients taking } \\
\text { no prednisone }\end{array}$} \\
\hline & No & $\%$ & No & $\%$ \\
\hline $\begin{array}{l}\text { No of patients } \\
\text { Sex: }\end{array}$ & 157 & 100 & 54 & 100 \\
\hline $\begin{array}{l}\text { Female } \\
\text { Male } \\
\text { Age: }\end{array}$ & $\begin{array}{l}62 \\
95\end{array}$ & $\begin{array}{l}39 \cdot 5 \\
60 \cdot 5\end{array}$ & $\begin{array}{l}21 \\
33\end{array}$ & $\begin{array}{l}38 \cdot 9 \\
61 \cdot 1\end{array}$ \\
\hline $\begin{array}{l}<20 \\
20-40 \\
>40\end{array}$ & $\begin{array}{l}26 \\
92 \\
39\end{array}$ & $\begin{array}{l}16 \cdot 6 \\
58 \cdot 6 \\
24 \cdot 8\end{array}$ & $\begin{array}{l}58 \\
38 \\
11\end{array}$ & $\begin{array}{r}9 \cdot 3 \\
70 \cdot 4 \\
20 \cdot 4\end{array}$ \\
\hline $\begin{array}{l}\text { Histology: } \\
\text { Lymphocyte predominance }\end{array}$ & 2 & $1 \cdot 3$ & & \\
\hline Nodular sclerosis & 110 & $70 \cdot 1$ & 41 & $75 \cdot 9$ \\
\hline Mixed cellularity & 30 & $19 \cdot 1$ & 9 & $16 \cdot 7$ \\
\hline $\begin{array}{l}\text { Lymphocyte depletion } \\
\text { Unclassified }\end{array}$ & $\begin{array}{l}6 \\
9\end{array}$ & $\begin{array}{l}3 \cdot 8 \\
5 \cdot 7\end{array}$ & $\begin{array}{l}2 \\
2\end{array}$ & $\begin{array}{l}3 \cdot 7 \\
3 \cdot 7\end{array}$ \\
\hline Site*: & & & & \\
\hline Nodes & 38 & $24 \cdot 2 \dagger$ & 23 & $42 \cdot 6 \dagger$ \\
\hline Lung & 53 & $\begin{array}{l}33 \cdot 8 \\
10 \cdot 8\end{array}$ & $\begin{array}{r}12 \\
4\end{array}$ & $\begin{array}{r}22 \cdot 2 \\
7.4\end{array}$ \\
\hline $\begin{array}{l}\text { Liver } \\
\text { Osseous }\end{array}$ & 9 & $\begin{array}{r}10.8 \\
5.7\end{array}$ & 4 & $7 \cdot 4$ \\
\hline Bone marrow & 39 & $24 \cdot 8$ & 10 & $18 \cdot 5$ \\
\hline Other & 2 & $1 \cdot 3$ & 1 & 1.9 \\
\hline Prior irradiation & 118 & $75 \cdot 2 \dagger$ & 53 & $98 \cdot 2 \dagger$ \\
\hline No prior irradiation & 39 & $24 \cdot 8^{\dagger}$ & 1 & $1.9 \dagger$ \\
\hline
\end{tabular}

${ }^{*}$ Most advanced site, in order listed.
$+\mathrm{P}<0.05$.

\section{Results}

The complete remission rate for those patients who received prednisone in cycles 1 and 4 was $90.3 \%$ compared with $93.3 \%$ in those who received no prednisone but completed at least four cycles of MOP $(P=0.52)$ (table III). The complete remission rate for all patients who received some prednisone was $81.5 \%$ compared with $77.8 \%$ for those who received no prednisone $(P=0.66)$. The first group of patients had a high complete remission rate because, by definition, it excluded patients who relapsed before completing four cycles of treatment.

TABLE III-Effect of prednisone on complete remission rate

\begin{tabular}{|c|c|c|c|c|}
\hline & \multirow{2}{*}{$\begin{array}{c}\text { No of } \\
\text { patients }\end{array}$} & \multicolumn{2}{|c|}{ Complete remissions } & \multirow{2}{*}{$\underset{\text { value }}{\mathbf{P}}$} \\
\hline & & No & $\%$ & \\
\hline $\begin{array}{l}\text { Prednisone in cycles } 1 \text { and } 4 \\
\text { No prednisone in } 4 \text { cycles } \\
\text { Some prednisone } \\
\text { No prednisone }\end{array}$ & $\begin{array}{r}113 \\
45 \\
157 \\
54\end{array}$ & $\begin{array}{r}102 \\
42 \\
128 \\
42\end{array}$ & $\begin{array}{l}90 \cdot 3 \\
93 \cdot 3 \\
81 \cdot 5 \\
77 \cdot 8\end{array}$ & $\left\{\begin{array}{l}0.52 \\
0.66\end{array}\right.$ \\
\hline
\end{tabular}

$\%$ of

potients

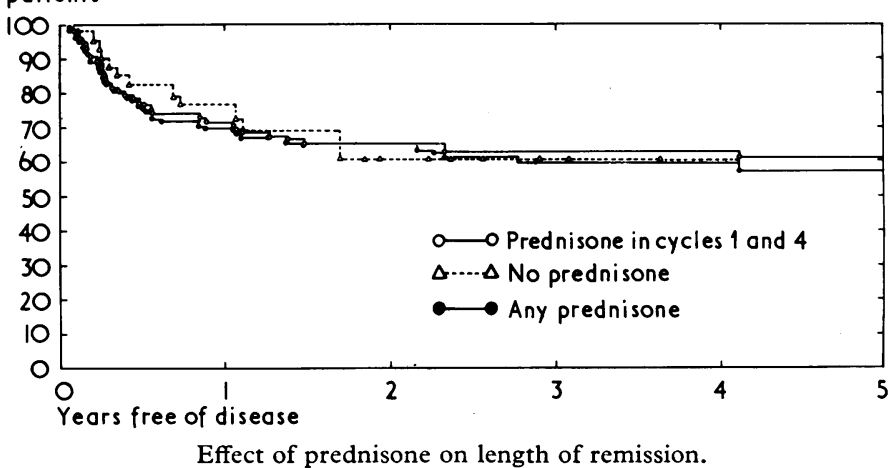

The length of remission in complete responders in all groups was comparable, with a $60 \%$ probability of being disease free $30-60$ months after completing chemotherapy (see figure).

Because there were significant differences between the groups in numbers of patients aged under 20, sites of disease (nodes and lung), and previous irradiation, we analysed the complete response rate and length of remission of these subgroups separately. There were no significant differences in either complete response rate or length of remission between any of the subgroups when comparing those who did and did not receive prednisone.

\section{Discussion}

Since the introduction of MOPP chemotherapy prednisone has been used routinely in the drug combination. When Castellino et $a l^{3}$ associated radiation pneumonitis or pericarditis with prednisone withdrawal, however, prednisone was eliminated from the regimen in those patients who had had mantle irradiation at Stanford. A British study ${ }^{4}$ recently compared prospectively complete remission rates in 90 patients with stage IV Hodgkin's disease and found a $44^{\circ}$, complete remission rate in those who were given MOP without prednisone and an $80 \%$ complete remission rate in those given MOPP with prednisone (oral prednisone $25 \mathrm{mg} / \mathrm{m}^{2}$ was given on days 1 to 14 of every cycle).

We found no differences in either complete remission rate or length of remission between patients who received prednisone in cycles 1 and 4, those who received no prednisone, and those who received some prednisone. Because this was a retrospective analysis with some patient selection we analysed the complete response rate and remission duration for all subgroups of unequal size. Like others, ${ }^{89}$ we found that prior irradiation had 
no effect on either the complete response rate or the length of remission within each subgroup. Similarly, the sites of disease (nodes and lung) and the patients' ages (under 20) did not significantly influence either complete response rates or the length of remission between the prednisone and no-prednisone groups.

Although our data do not agree with those of the British study there are some major differences between the two studies. Our study was a retrospective analysis comparing groups of patients treated over different times. Most of those patients receiving prednisone were treated before 1974 or had had no mediastinal irradiation. A prospective randomised study of strictly comparable patients is always to be preferred in judging the value of a treatment, but we did evaluate the effect of patient selection by analysing each subgroup and found no significant differences in the complete response rate or length of remission between those who did and did not receive prednisone.

A possible explanation for the different findings of the British study is that good partial responses might have been converted into clinical complete responses by prednisone. Whether or not these apparent complete responses last will be known only after three to five years. The value of chemotherapy for Hodgkin's disease must be measured not only by the complete remission rate but also by the length of the remissions. Current studies indicate that about $60^{\circ}{ }_{0}$ of the patients should remain in complete remission for at least five years and probably indefinitely. ${ }^{910}$

The unusually low complete response rate of $44^{\circ}{ }_{0}$ in the British group who had no prednisone is disturbing. The rate is significantly lower than that reported by most other groups. ${ }^{9} 10$ Since the report of the British study was a preliminary one, it does not provide information on the amount of myelosuppressive drugs actually given in the two treatment groups. Their results could be explained if more mustine and procarbazine had been given to the prednisone group because of higher peripheral blood counts, which might be expected in that group.

The British study used prednisone in every cycle of their treatment programme. This may have brought out differences that are not as apparent when the steroid is used for only two cycles. But our results with a regimen without prednisone are quite comparable to those in the British patients who received prednisone in every cycle. Furthermore, most of these complete responses to MOP have produced durable remissions for at least five years. This suggests that eliminating prednisone does not reduce the efficacy of the MOPP regimen.

These studies were supported in part by grants CA-08122 and CA-05838 from the National Cancer Institute, National Institutes of Health, Bethesda, Maryland, USA.

\section{References}

1 Frei, E, et al, Cancer Research, 1966, 26, 1284.

2 DeVita, V T, et al, Annals of Internal Medicine, 1970, 73, 881

${ }^{3}$ Castellino, R A, et al, Annals of Internal Medicine, 1974, 80, 593.

4 Report from the British National Lymphoma Investigation, British Medical fournal, 1975, 3, 413.

5 Lukes, R J, et al, Cancer Research, 1966, 26, 1311.

${ }^{6}$ Kaplan E L, and Meier, P, fournal of the American Statistical Association, 1958, 53, 457.

7 Gehan, E A, Biometrika, 1965, 52, 203.

${ }^{8}$ Moore, M R, et al, Cancer, 1973, 32, 52.

9 Portlock, C S, et al, Proceedings of the American Association of Cancer Research and American Society for Clinical Oncology, 1976, 17, 248.

11 DeVita, V, et al, Proceedings of the American Association of Cancer Research and American Society for Clinical Oncology, 1976, 17, 269.

\title{
New technique for investigating bacterial flora of female periurethral area
}

\author{
W BRUMFITT, J M T HAMILTON-MILLER, M BAKHTIAR, J COOPER
}

British Medical fournal, 1976, 2, 1471-1472

\section{Summary}

The bacterial flora of the female periurethral area was studied by impression cultures taken with polystyrene sponges, the results being recorded by photographic contact printing. With this technique it is possible to observe the preferential colonisation of different areas by different organisms and to detect persistent colonisation by pathogens. In assessing the possible aetiological importance of these results, and especially in comparing them with the findings of other workers, it is essential to use correct anatomical nomenclature.

\footnotetext{
Department of Medical Microbiology, Royal Free Hospital, London NW3 2QG

W BRUMFITT, FRCP, professor

J M T HAMILTON-MILLER, MRCPATH, senior lecturer

M BAKHTIAR, MSC, research assistant

J COOPER, MB, clinical assistant
}

\section{Introduction}

The role of bacterial colonisation of the regions surrounding the female urethral meatus in the initiation of urinary tract infections has long been a source of speculation. Several attempts have been made to isolate pathogenic strains of bacteria from patients subject to relapse or reinfection by swabbing various sites within and around the vestibule, ${ }^{1-6}$ but the conclusions drawn have varied. A major reason for this may well be the lack of standardisation of both microbiological technique and anatomical nomenclature. These two factors combined constitute such a problem that it seems doubtful whether any of the reported studies could be repeated by other workers. We therefore draw attention to the official definitions (according to anatomy texts) of the terms "vestibule" (the whole area inside the labia minora), "introitus" (synonymous with the vaginal orifice), and "perineum" (the area between the thighs from the coccyx to the pubis). In gynaecology and obstetrics, however, the perineum is commonly referred to as the region between the posterior commissure of the labia majora and the anus.

The confusion that has arisen through imprecise nomenclature includes "introital" used apparently synonymously with "vaginal vestibular"' (we have been unable to find a definition of the term "vaginal vestibule"), "vaginal,"5 and "periurethral." " Even as simple a word as periurethral has been defined in more than one way. (Bailey et $a l^{4}$ termed as 